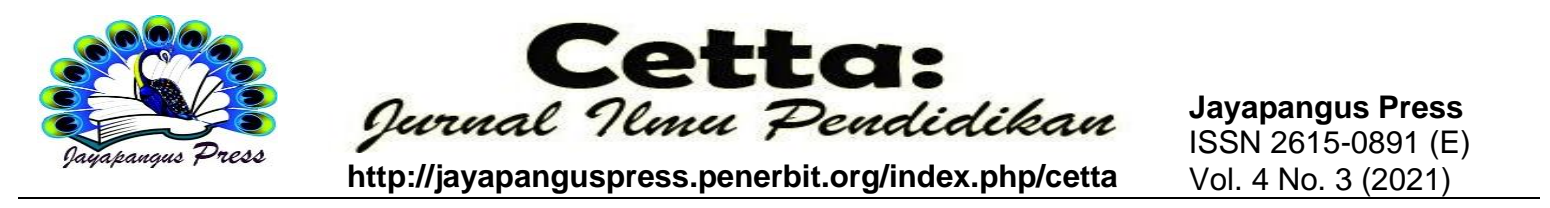

\title{
Implementasi Pendidikan Karakter Berbasis Keagamaan Dalam Memperkuat Ketahanan Keluarga Pada Masa Pandemi Di Kecamatan Karangasem
}

\author{
I Wayan Sudiarta ${ }^{1}$, I Kadek Edi Palguna ${ }^{2}$ \\ ${ }^{12}$ Sekolah Tinggi Agama Hindu Negeri Mpu Kuturan Singaraja \\ 1udi_wy@yahoo.com, ${ }^{2}$ palgunaedi@gmail.com
}

\begin{tabular}{l}
\hline Keywords: \\
\hline Religious Based \\
Character \\
Education; \\
Family Resilience \\
\hline
\end{tabular}

\begin{abstract}
The Covid 19 outbreak in Indonesia has spread to various regions, becoming the epicenter of the spread of the virus. This makes the joints of family resilience to be shaky due to various impacts. The purpose of this study is to determine the need for religious-based character education to be implemented, how to implement Religious-Based character education in strengthening family resilience during the pandemic in Karangasem District, and the implications of Religious-Based Character Education on Family Resilience during the Pandemic Period in Karangasem District. The method used is descriptive qualitative with the type of data used in this study is qualitative data. The source of data used is primary data, namely data obtained from informants and secondary data in the form of literature as supporting primary data. The process of data analysis in an interactive form. The results of the research obtained are considering the many problems faced by the community in Karangasem District, especially problems in the aspects of tourism and trade, it is necessary to implement character education during the pandemic for family resilience, the form of Implementation of Religious-Based Character Education, which is reflected in the teachings of Tri Kaya Parisuda, namely thinking (manacika), taste/intention (wacika) and exercise (Kayika), and the implications of religious-based character education on family resilience during a pandemic in Karangasem district, namely being able to strengthen psychological resilience with awareness to be able to control oneself and accept all conditions sincerely. and keep trying and keep trying to find solutions and solutions. From some of the informants' explanations, the implementation of religious-based character education is very important to strengthen family resilience during the pandemic.
\end{abstract}

Kata Kunci:

Pendidikan

Karakter Berbasis

\section{Abstrak}

Wabah Covid 19 di Indonesia telah meluas ke berbagai daerah menjadi episentrum penyebaran virus tersebut. Hal tersebut 
Keagamaan;

Ketahanan

Keluarga menjadikan sendi-sendi ketahanan keluarga menjadi goyah karena berbagai dampak yang ditimbulkan. Tujuan dari penelitian ini adalah untuk mengetahui perlunya pendidikan karakter berbasis keagamaan diimplementasikan, bagaimana implementasi pendidikan karakter Berbasis Keagamaan dalam memperkuat ketahanan keluarga pada masa pandemi di Kecamatan Karangasem, dan implikasi pendidikan karakter berbasis keagamaan terhadap ketahanan keluarga pada masa pandemi di Kecamatan Karangasem. Metode yang digunakan adalah bersifat deskriftif kualitatif dengan jenis data yang digunakan dalam penelitian ini adalah data kualitatif. Sumber data yang digunakan data primer yaitu data yang didapat dari informan dan data sekunder yaitu berupa literatur-literatur sebagai penunjang data primer. Proses analisis data dalam bentuk interaktif. Hasil penelitian yang diperoleh adalah Mengingat banyak permasalahan yang dihadapi oleh masyarakat di Kecamatan Karangasem terutama permasalahan pada aspek pariwisata dan perdagangan maka perlu diimplementasikan pendidikan karakter di masa pandemi untuk ketahanan keluarga, bentuk Implementasi Pendidikan Karakter Berbasis Keagamaan yaitu tercermin dalam ajaran Tri Kaya Parisuda yaitu olah pikir (manacika), olah rasa/karsa (wacika) dan olah raga (Kayika), dan implikasi pendidikan karakter berbasis keagamaan terhadap ketahanan keluarga pada masa pandemi di Kecamatan Karangasem yaitu mampu memperkuat ketahanan psikologis dengan kesadaran untuk mampu mengendalikan diri dan menerima segala kondisi dengan ikhlas dan tetap berusaha dan terus berikhtiar untuk mencari solusi dan jalan keluar. Dari beberapa penjelasan informan implementasi pendidikan karakter berbasis keagamaan sangat penting untuk memperkuat ketahanan keluarga di masa pandemi.

\section{Pendahuluan}

Dunia sedang dihadapkan pada permasalahan global yakni Wabah Corona Virus Disease (COVID 19) atau lebih dikenal dengan Virus Corona. Wabah Covid 19 di Indonesia telah meluas ke berbagai daerah menjadi episentrum penyebaran virus tersebut. Pemerintah memberlakukan social distancing dan beberapa daerah memberlakukan Pembatasan Sosial Berskala Besar (PSBB) guna memutus mata rantai penyebaran covid19. Hal tersebut mengakibatkan hampir seluruh sektor terdampak, tak hanya kesehatan, sektor ekonomi juga mengalami dampak serius akibat pandemi virus corona. Dampak juga berimbas pula dari segi, ekonomi, pendidikan, social, budaya.

Beberapa waktu lalu pemerintah menghimbau masyarakat untuk WFH (work from home), bekerja dari rumah, khususnya bagi orang-orang yang berada di usia rentan. 
Anak-anak dan para siswa serta mahasiswa juga diarahkan untuk belajar dari rumah. Sebagian besar masyarakat menahan diri untuk beraktivitas di luar. Bekerja, belajar dan beribadah dilakukan di rumah. Sebagian masyarakat juga terkena dampak PHK, pemberhentian hubungan kerja. Kondisi ini menambah berat dari sisi ekonomi. Sementara kebutuhan hidup sehari-hari terus menuntut untuk dipenuhi. Kebutuhan makan tidak dapat ditunda. Semua ini menjadi tantangan besar bagi masyarakat dan bangsa Indonesia. Selain ekonomi, aspek lain juga terdampak. Aspek sosial, aspek psikologis dan spiritual juga dapat dirasakan dampaknya. Secara sosial, budaya berkumpul dalam berbagai bentuk kegiatan sementara ini dihilangkan. Seperti pertemuan-pertemuan, forum-forum kajian yang ada di masyarakat, semua terhenti untuk sementara waktu.

Aktivitas sholat jamaah di masjid juga terhambat. Walaupun hal itu dalakukan maka harus tetap menjaga protokol kesehatan, seperti cuci tangan, menggunakan masker, bawa sajadah sendiri, 5 berjarak satu jamaah dengan lainnya. Semua itu kadang dirasa menyulitkan sehingga lebih nyaman menahan diri di rumah saja. Aktivitas belajar mengajar yang biasanya hiruk pukuk ramai di sekolah, anak-anak bercanda dan berkejaran satu dengan yang lain, saat ini menjadi sepi. Sekolah dan ruangan yang ada tampak kosong. Hanya ada beberapa guru yang secara bergilir melaksanakan tugas piket di sekolah. Semua anak belajar dari rumah (BDR).

Tugas-tugas yang diberikan oleh guru disampaikan melalui fasilitas internet seperti WA, google classroom, zoom meeting dan sebagainya. Semua itu menjadi tantangan tersendiri bagi sekolah dan keluarga dalam menghadapai situasi yang tidak pasti. Dibutuhkan kreativitas dan daya juang yang tinggi untuk bisa tetap bertahan. Orang tua atau wali murid yang semestinya menunaikan kewajiban keuangan juga berada pada posisi yang sulit karena lahan pekerjaan juga semakin berat. Lembaga pendidikan harus tetap bertahan dengan segala daya upaya, agar tetap bisa menggaji para guru yang telah bertahun-tahun mengabdikan diri di lembaga pendidikan untuk turut mencerdaskan kehidupan bangsa. Terlebih dalam ketahanan keluarga sangat berdampak akibat pandemik saat ini.

Kemampuan membangun ketahanan keluarga menjadi satu hal yang harus bisa diupayakan. Ketahanan keluarga merupakan kondisi dinamis suatu keluarga yang memiliki ketangguhan dan keuletan secara fisik, psikis, mental dan spiritual sehingga mampu mewujudkan kehidupan yang mandiri, mengembangkan diri dan keluarganya sehingga terbangun keluarga yang harmonis sejahtera lahir dan batin. Ada beberapa hal 
terkait dengan ketahanan keluarga. Secara umum dapat dijelaskan sebagai berikut. Pertama ketahanan psikologis. Ketahanan psikologis merupakan kemampuan sebuah keluarga untuk mengelola dan membangun emosi positif dalam keluarga sehingga tercipta konsep diri yang positi. Bila anggota keluarga telah memiliki konsep diri positif maka peristiwa apapun yang dihadapi akan diterima secara positif pula. Artinya keluarga memiliki kemampuan untuk mengambil hikmah dari setiap peristiwa yang terjadi, apapun bentuknya. Tidak mudah 6 menyalahkan orang lain atau peristiwa yang terjadi, namun lebih pada mencari solusi dari segala tantangan dan persoalan yang ada di depan mata.

Kemampuan mengelola emosi dan membangun konsep diri yang positif ini menjadi kunci dalam menghadapi masalah-masalah keluarga yang bersifat non fisik. Kedua, ketahanan Ekonomi. Ketahanan ekonomi erat kaitannya dengan kemampuan mengelola ekonomi keluarga, sehingga kebutuhan dasar pangan, papan dan sandang dapat dipenuhi walaupun secara minimalis. Kondisi ini menuntut adanya sumber penghasilan keluarga. Sumber penghasilan tidak harus menjadi pegawai di pemerintahan maupun swasta, namun berwirausaha bahkan bisa memberikan hasil yang tak terduga. Tujuan yang pasti adalah dapat memenuhi kebutuhan keluarga. Selain itu pemanfaatan lahan yang ada di sekitar rumah untuk kegiatan produktif juga sangat membantu untuk meningkatkan ketahanan keluarga. Seperti menanam sayuran dan tanaman lain yang cepat panen. Ternak lele, ayam atau lainnya yang dapat mendukung pemenuhan gizi keluarga. Berbagai alternatif lain dapat digali untuk mendapatkan solusi dari keterbatasan ekonomi. Ketiga ketahanan sosial. Ketahanan sosial erat kaitannya dengan kemampuan keluarga untuk membangun sinergi dengan lingkungan sosialnya.

Walaupun sebagian besar masyarakat menahan diri di rumah, namun tidak memutus jaringan komunikasi dan informasi antar warga. Dengan jalinan silaturrahim dan komunikasi yang baik maka akan terbangun ikatan dan komitmen untuk saling membantu, saling memberi dukungan saat ada permasalahan yang menimpa anggota keluarga. Jiwa gotong royong perlu dikuatkan. Kesediaan membantu saudara atau tetangga yang sedang dalam kesusahan perlu menjadi perhatian semuanya. Kebutuhan sekunder perlu dikesampingkan dulu agar dapat terpenuhi kebutuhan primer yang tidak dapat ditunda. Kesediaan untuk membantu orang lain akan meringankan beban sosial saat keluarga menghadapi permasalahan.

Keempat ketahanan spiritual. Ketahanan spiritual erat kaitannya dengan kemampuan keluarga untuk memahami dan menerapkan nilai-nilai agama dalam 
kehidupan sehari-hari. Diawali dari praktik kehidupan dalam rumah tangga. Agama menjadi fondasi yang kokoh, sekaligus atap yang melindungi dalam mengarungi bahtera kehidupan. Agama menjadi benteng, tumpuan dan sandaran yang kokoh dalam menghadapi persoalan. Tanpa pemahaman nilai-nilai dasar keagamaan dan sandaran vertikal yang kokoh maka perjalanan hidup akan mudah limbung saat menghadapi goncangan. Apalagi di masa pandemi covid saat ini yang memberikan dampak di hampir semua lini kehidupan. Keluarga perlu diarahkan untuk mengkaji nilai-nilai kehidupan yang diajarkan dalam syariaat agama. Sumber belajar telah banyak terbuka. Tayangan online juga sangat banyak fariasinya, tinggal memilih sesuai selera. Komitmen untuk belajar dan terus belajar, itu yang lebih penting. Pada akhirnya ketahanan spiritual akan mengarahkan diri untuk bersikap dan berperilaku sesuai dengan nilai yang dipahami, dan meyakini bahwa semua peristiwa yang terjadi tidak lepas dari kehendak dan kekuasaan yang maha kuasa (Hibana, 2020)

Untuk mengatasi masalah tentang ketahanan keluarga ada berbagai cara yang dilakukan untuk memperkuat ketahanan keluarga tersebut akibat pandemi. Salah satu dari cara memperkuat ketahanan keluarga pada masa pandemi yaitu dengan pendidikan karakter yang di terapkan dari berbagai wilayah. Lebih lanjut pendidikan karakter tersebut harus selalu ditanamkan kepada masyarakat agar tercapainya harmonisasi dalam masyarakat. Di samping itu, sesuai dengan Perpres Nomor 87 tahun 2017 tentang penguatan pendidikan karakter dimana dalam rangka mewujudkan bangsa yang berbudaya melalui penguatan nilai-nilai religius, jujur, toleran, disiplin, bekerja keras, kreatif, mandiri, demokratis, rasa ingin tahu, semangat kebangsaan, cinta tanah air, menghargai prestasi, komunikatif, cinta damai, gemar membaca, peduli lingkungan, peduli sosial, dan bertanggung jawab, perlu penguatan pendidikan karakter. Penguatan pendidikan karakter sebagaimana dimaksud di atas merupakan tanggung jawab bersama keluarga, satuan pendidikan, dan masyarakat yang dalam hal ini berhubungan dengan konsep spiritualisme dengan menjalankan ajaran agama.

\section{Metode}

Metode yang digunakan adalah bersifat deskriftif kualitatif dengan jenis data yang digunakan dalam penelitian ini adalah data kualitatif. Sumber data yang digunakan data primer yaitu data yang didapat dari informan dan data sekunder yaitu berupa literaturliteratur sebagai penunjang data primer. Penentuan informan dilakukan dengan teknik 
sampling snowball. Teknik pengumpulan data ini digunakan beberapa teknik yaitu teknik studi dokumentasi, observasi, dan wawancara. Proses analisis data dalam bentuk interaktif yaitu mengolah data merupakan suatu usaha yang kongkrit untuk membuat data agar mampu menjelaskan semua permasalahan secara komprehensif. Hal tersebut dilakukan dengan mengumpulkan data yang telah diperoleh melalui metode observasi, wawancara, studi dokumen. Setelah data terkumpul kemudian dipilah atau dikatagorikan dan direduksi, agar diketahui data mana yang perlu ditambahkan. Selanjutnya dianalisis dan diinterppretasikan dengan cara menyeleksi serta membandingkan data yang diperoleh dari informan. Dengan demikian data yang dikumpulkan akan terjamin keakuratan dan keabsahanya.

\section{Hasil dan Pembahasan}

\section{Gambaran Umum Lokasi Penelitian}

Karangasem adalah sebuah kecamatan di Kabupaten Karangasem, Provinsi Bali, Indonesia. Kecamatan ini berjarak sekitar $65 \mathrm{Km}$ dari Kota Denpasar. Amlapura yang merupakan ibu kota Kabupaten Karangasem ada di kecamatan ini. Luas wilayah Kecamatan Karangasem adalah 94,23 km² dengan penduduk 97.584 jiwa.

Batas wilayah kecamatan karangasem meliputi sebelah utara Kecamatan Abang yaitu sebuah kecamatan di Kabupaten Karangasem, Bali, Indonesia. Luasnya adalah $134,05 \mathrm{~km}^{2}$. Pada tahun 2010, penduduknya berjumlah 60.965 jiwa, sebelah timur dan selatan Selat Badung yaitu selat yang memisahkan antara Pulau Bali dengan Pulau Nusa Penida beserta pulau-pulau kecil di sekitarnya., dan sebelah Barat Kecamatan Manggis dan Kecamatan Bebandem dimana Kecamatan Manggis adalah sebuah kecamatan di Kabupaten Karangasem, Provinsi Bali, Indonesia. Luasnya adalah 69,83 km². Pada tahun 2002, penduduknya berjumlah 40.600 jiwa dan Kecamatan Bebandem adalah sebuah kecamatan di Kabupaten Karangasem, Bali, Indonesia. Luasnya adalah 81,51 km². Pada tahun 2002, penduduknya berjumlah 43.086 jiwa.

Kecamatan Karangasem terbagi menjadi 3 (tiga) kelurahan yakni kelurahan Subagan, Padangkerta, Karangasem dan 11 (sebelas) desa, yakni Desa Bugbug, Desa Bukit, Desa Karangasem, Desa Padangkerta, Desa Pertima, Desa Seraya Barat, Desa $\underline{\text { Seraya Tengah, Desa Seraya Timur, Desa Subagan, Desa Tegallinggah, dan Desa Tumbu. }}$ 


\section{Perlunya Pendidikan Karakter Berbasis Keagamaan diimplementasikan dalam Memperkuat Ketahanan Keluarga Pada Masa Pandemi di Kecamatan Karangasem}

Permasalahan yang sekarang dihadapi keluarga terutama di Kecamatan Karangasem adalah gaya pengasuhan cenderung permisif. Hal ini disebabkan karena orang tua sama-sama sibuk bekerja, kurangnya waktu berkualitas bersama anak sebelum pandemi. Waktu berkualitas bersama anak sering tergadai oleh alasan pekerjaan. Kedua orang tua sibuk, sehingga selalu tergesa-gesa saat bersama anak. Makan bersama anak dengan tergesa-gesa, hingga tak jarang anak disuapi supaya cepat selesai dan bisa berangkat kerja ontime. Mengajari belajar di rumah sambil memegang gadget dengan alasan bekerja online. Bahkan berbincang-bincang dengan anak untuk sekedar berbagi cerita hari ini, pun sering tidak mendapat bagian waktu.

Orang tua merasa memiliki banyak uang, hingga akhirnya mereka lebih banyak memberi materi sebagai permintaan maaf pada anak. Namun mereka abai bahwa yang diperlukan anak sejatinya adalah kasih sayang dan waktu luang. Itulah mengapa menurut pandangan orang tua anak menjadi sulit dikontrol. Orang tua akan kehilangan banyak waktu bersama anak. Selain itu, orang tua juga akan kehilangan moment anak mulai berjalan, moment anak berbicara dan moment perkembangan yang lain. Keberhasilan mendidik anak bukan hanya terletak pada prestasi akademik, tetapi yang terpenting adalah pada karakter positif anak. Mempersiapkan generasi tangguh bukan perkara mudah. Perlu ada sinergi dan komitmen dari kedua orang tua. Karena kewajiban mendidik anak berada di tangan kedua orang tua, yaitu ayah dan ibu.

Rihlah (2020) dalam penelitiannya mengungkapkan bahwa pendidikan karakter dalam keluarga selama masa pandemi berada pada kategori mulai berkembang. Mulai berkembang dapat diartikan bahwa pendidikan karakter yang dilakukan dalam keluarga masih sangat minim. Hal ini disebabkan karena minimnya pengetahuan dan kreativitas orang tua dalam membuat aktivitas yang menyenangkan bersama anak, sehingga anak merasa bosan selama pandemi. Ketika anak merasa bosan dan hubungan antara orang tua dengan anak tidak hangat, maka akan sulit bagi orang tua untuk memberikan pendidikan karakter. Kantun mengungkapkan bahwa selama pandemi, orang tua menjalankan beban ganda, yaitu bekerja dari rumah dan mengawasi anak belajar di rumah.

Pandemi covid-19 dapat dikatakan sebagai shock therapy untuk orang tua. orang tua hendaknya berdamai dengan keadaan dan tetatap kreatif dalam mencari nafkah, tetap 
bertanggungjawab kepada keluarga, tetap ceria walaupun ada permasalahan, serta tetap saling menghargai (wawancara, tanggal 21 Mei 2021). Meyakini bahwa mau tidak mau, suka tidak suka memang keadaan harus seperti ini. Lebih lanjut wardana mengatakan bahwa di masa pandemi ini pendidikan di keluarga sangat penting untuk mempertahankan ketahanan keluarga, karena banyak permasalahan yang dihadapi sebagai dampak dari pandemi. Di sini orang tua sangat berperan agar tidak goyah dan frustasi dalam mengahdapi masalah di keluarga (wawancara, tanggal 3 Juni 2021). Maka sebagai orang tua yang harus belajar untuk beradaptasi dengan keadaan. Hal ini berakibat pada hasil pendidikan yang pandai namun tidak berkarakter.

Sebab lain yang melatarbelakangi yaitu kesibukan orang tua, dan ketidaktahuan orang tua tentang cara membentuk karakter positif pada anak. Hal ini disebabkan karena orang tua telah terbiasa menyerahkan tanggung jawab Peran Keluarga dalam Pendidikan Karakter, Sehingga saat pandemi covid-19 melanda dan anak lebih banyak menghabiskan waktu di rumah, orang tua kewalahan cara mendidik karakter anak. Beberapa hasil penelitian di atas menjadi pondasi peneliti untuk memngetahui lebih lanjut tentang peran keluarga dan cara pengasuhan keluarga yang ideal untuk membangun karakter anak di masa pandemi dalam membangunketahanan keluarga.

Dari pemaparan di atas maka sangat penting pendidikan karakter dalam memperkuat ketahanan keluarga di masa pandemi, agar bisa menjadikan pandemi covid19 dapat dikatakan sebagai shock therapy untuk orang tua. orang tua hendaknya berdamai dengan keadaan dan tetatap kreatif dalam mencari nafkah, tetap bertanggungjawab kepada keluarga, tetap ceria walaupun ada permasalahan, serta tetap saling menghargai. di masa pandemi ini pendidikan di keluarga sangat penting untuk mempertahankan ketahanan keluarga, karena banyak permasalahan yang dihadapi sebagai dampak dari pandemi, sehingga orang tua sangat berperan agar tidak goyah dan frustasi dalam mengahdapi masalah di keluarga.

Lebih lanjut dengan lesunya sektor pariwisata di Kecamatan Karangasem dampak ekonomi sangat dirasakan oleh masyarakat, karena sebagian besar masyarakat di Kecamatan Karangasem bergerak di sektor Pariwisata, perdagangan, pertanian, nelayan. Yang paling berdampak pada sektor tersebut adalah pariwisata. Kantun (wawancara tanggat 21 Mei 2021) dimana informan merupakan salah satu pelaku pariwisata mengemukakan bahwa apabila pandemi ini terus berkepajangan maka sektor pariwisata akan semakin terpuruk. Banyak pelaku pariwisata yang beralih profesi yaitu ada yang 
menjadi buruh bangunan, petani, pedagang. Hal tesebut merupakan hal yang sangat sulit untuk dibayangkan. Di samping itu Sesuai dengan Perda Provinsi Bali Nomor 2 tahun 2012, pariwisata Bali berlandaskan kebudayaan yang mampu menggerakkan potensi kepariwisataan dalam dinamika kehidupan lokal, nasional dan global.

Saat ini perkembangan pariwisata Bali mengalami penurunan drastis bahkan sampai minus semenjak tahun 2020, yang melumpuhkan berbagai sektor khususnya di sektor ekonomi, terutama di bidang usaha pariwisata serta di bidang ketenagakerjaan, yang bisa dilihat pada pemutusan hubungan kerja (PHK) serta ditutupnya usaha-usaha pariwisata akibat penurunan permintaan dari wisatawan. Di sektor sosial terlihat dari perilaku dan kebiasaan masyarakat, pelaku pariwisata dan wisatawan. Aturan dari pemerintah untuk diterapkan di masyarakat sesuai dengan pencegahan penyebaran covid19 lebih luas lagi dikenal dengan istilah 3M (mencuci tangan, memakai masker, menjaga jarak) serta CHSE (cleanliness, healthy, safety dan environment) yang meliputi program penerapan protokol kesehatan.

Sektor lingkungan di masa pandemi ini memberikan dampak positif, mengingat aktivitas serta eksploitasi alam yang secara berlebihan kini dapat diminimalisir dan berkurang. Polusi yang diakibatkan oleh aktivitas pariwisata juga berkurang sehingga meningkatkan kualitas udara dan lingkungan. Melihat kondisi ini, pemerintah sangat memegang peran penting dalam mengeluarkan kebijakan bagi masyarakat dan komponen pariwisata (stakeholder) sehingga dapat tetap beraktivitas dan produktif dalam pergerakan di sektor ekonomi. Di sektor pariwisata, kebijakan pemerintah sangat dibutuhkan dan dapat direalisasikan segera dengan harapan kondisi pariwisata dapat berangsur-angsur pulih kembali (Purwahita, dkk, 2021 : 1).

Dampak pandemi juga dirasakan pada sektor perdagangan di Kecamatan Karangasem, hal tersebut diutarakan oleh informan marti (wawancara tanggal 21 Mei 2021) bahwa yang dirasakan pada masa pandemi sangat berdampak pada sektor perdagangan. Para pedagang menjerit akibat pandemi Covid-19 yang melanda masyarakat. Covid-19 merupakan penyakit yang mudah menyebar kapan dan dimanapun melalui kontak fisik maupun non fisik. Penyebaran covid-19 tidak memandang baik itu dari kalangan elit maupun kalangan menengah ke bawah. Salah satu tempat penyebaran covid-19 adalah pasar, karena pasar merupakan tempat berkumpulnya banyak orang dan terjadi transaksi jual-beli yang melibatkan kontak fisik didalamnya. Pemerintah sudah melakukan Pembatasan Sosial Berskala Besar atau PSBB dimana ada pembatasan 
kegiatan di tempat-tempat yang menyebabkan kerumunan seperti pasar, tempat ibadah, dan kegiatan-kegiatan yang mengundang banyak orang. Dampak yang paling dirasakan oleh para pedagang adalah penurunan pendapatan akibat PSBB. Para pedangang kebingungan untuk menjual barang dagangannya karena sulitnya mendapatkan pembeli dimasa pandemi, sehingga membuat pendapatan turun drastis. seperti yang dirasakan oleh pedagang kelontong, pedagang sayuran, pedagang buah-buahan, pedagang ikan, pedagang baju, pedagang daging, pedagang bumbu, pedagang ATK dan mainan, pedagang sandal dan sepatu, toko seluler, pedagang makanan jadi, pedagang online, pedagang jajanan dan pedagang asongan.

Dari beberapa permasalahan yang didapat dari informan, maka perlu adanya implementasi pendidikan karakter demi mempertahankan ketahanan keluarga akibat pandemi, sehingga masyarakat bisa bersabar, terima dengan keadaan yang telah terjadi semata-mata bukan disengaja tetapi memang harus terjadi yang merupakan titah Tuhan. Implementasi pendidikan karakter harus dimulai dari paling terkecil yaitu dari keluarga, karena keluarga merupakan tempat yang pertama dan utama dalam hal implementasi pendidikan karekter, apalagi pada situasi pandemi pendidikan formal seperti sekolah tidak ada aktifitas mengajar tatap muka. Di mana pembelajaran di masa pandemi diberlakukan secara daring.

Peran keluarga dalam mengimplementasikan pendidikan karakter berbasis keagamaan sangat perlu di masa pandemi, tentulah akan mengalami sedikit perbedaan pada masa pandemi dan sebelum pandemi. Mengingat waktu yang dihabiskan bersama anak lebih banyak juga. Adapun beberapa hal yang harus diperhatikan keluarga dalam menanamkan pendidikan karakter pada anak di masa pandemi. Marti menyampaikan prinsip pengasuhan anak kepada seluruh anggota keluarga dewasa yang ada dalam satu rumah, misal kakek, nenek, paman, bibi, dan sebagainya. Hal ini bertujuan supaya antar anggota keluarga memiliki kesepakatan cara mengasuh anak. Orang tua perlu menyatukan visi misi dalam mengasuh anak.

Menyamakan pandangan tentang pengasuhan, karena kebanyakan orang tua mempelajari pengasuhan dari orang tua mereka masing-masing. Ayah dan ibu mungkin membawa pandangan yang berbeda mengenai pengasuhan anak. Oleh karena itu, perlu ada kesepakatan-kesepakatan supaya tidak menimbulkan kebingungan pada anak. Kerjasama antar anggota keluarga, sikap saling menghormati, komunikasi yang seimbang, dan penyesuaian terhadap kebutuhan masing-masing, akan membantu anak 
dalam membentuk sikap positif (wawancara tanggal 21 Mei 2021). Anak akan memiliki gambaran peran seorang ayah dan peran ibu dengan baik (Santrock: 2011).

Adapun prinsip yang perlu disepakati antara lain penggunaan gadget terutama saat di depan anak, pembiasaan kata-kata positif, ritual keagamaan, dan sebagainya. Kedua, merencanakan kegiatan yang akan dilakukan bersama anak. Akan lebih baik bila anak diajak ikut serta berdiskusi. Hal ini bermanfaat supaya anak merasa dihargai pendapatnya. Merencanakan kegiatan bersama anak lebih tepat dilakukan bersama anak pada masa awal kanak-kanak. Ketiga, mendiskusikan aturan keluarga bersama anak dan menyepakatinya (Subarto:2020). Orang tua juga perlu memberi pengertian pada anak bahwa setiap keluarga memiliki aturan keluarga masing-masing. Dengan demikian, anak akan belajar memahami kondisi keluarganya dan tidak merasa iri dengan keluarga yang lain. Adapun aturan yang harus disepakati misalkan tidak menggunakan gadget saat berbincang.

Amaruddin (2020) menyampaikan bahwa media sosial memiliki dampak buruk terhadap karakter anak. Keluarga memiliki peran dalam memanajemen penggunaan media sosial untuk mempertahankan sikap santun anak. Keempat, melibatkan anak dalam pekerjaan rumah, tentunya dengan senang hati dan tanpa paksaan. Manfaat dari kegiatan ini adalah untuk menumbuhkan rasa tanggung jawab dan rasa memiliki pada anak. Ketika ada bagian rumah yang tidak nyaman, anak yang terbiasa melakukan pekerjaan rumah akan berinisiatif untuk segera membersihkan atau memperbaiki bagian tersebut. Oktaria (2020) menyampaikan bahwa pendidikan informal bersama keluarga harus bisa menghadirkan momentum menikmati hangatnya keluarga dan hak anak untuk bahagia bersama keluarga melalui aktivitas bersama yang dilakukan di dalam rumah. Kelima, mendampingi anak saat belajar, terutama saat menerima tugas dari sekolah.

Penerapan pembelajaran daring (dalam jaringan), menuntut setiap orang tua untuk menyediakan gadget guna mengetahui materi dan tugas yang diberikan guru. Oleh karena itu, saat anak belajar harus ada pendampingan. Hal ini selain bermanfaat untuk memantau belajar anak, membangun ikatan batin dengan anak, orang tua juga dapat meminimalisir dari penyalahgunaan gadget oleh anak. Seperti yang diungkapkan oleh Rahmi (2020), bahwa dengan mendampingi anak belajar, orang tua dapat mengenal karakter anak dan mengetahui cara memperlakukan anak dengan keunikan yang dimiliki. Keenam, mengobrol dengan anak merupakan cara untuk memperbaiki pengasuhan yang mungkin selama ini hilang atau belum maksimal. 
Orang tua dapat menghabiskan waktu bersama anak dengan topik kegiatan anak hari ini, perasaan anak akan suatu hal, keinginan anak, dan masih banyak lagi. Santrock (2011) juga mengungkapkan bahwa melalui interaksi dengan orang tua, anak belajar untuk mengekspresikan emosi dengan cara yang wajar. Penelitian Purandina Peran Keluarga dalam Pendidikan Karakter masa pandemi, bahwa orang tua yang membimbing anak dengan penuh kasih sayang, berinteraksi, melakukan aktivitas yang positif selama pandemi menghasilkan peningkatan nilai karakter. Ketujuh, melakukan ritual keagamaan bersama anak. Peran orang tua adalah mendidik dengan kelembutan dan kasih sayang membangun kebiasaan-kebiasaan positif, mampu menjadi contoh yang baik dan memberi makan yang halal dan baik. Kunci utama pendidikan keluarga terletak pada pendidikan rohani atau keagamaan (Tafsir: 2014).

Hyoscyamina (2020) juga membuktikan dalam penelitiannya, bahwa suasana agamis di rumah dapat memudahkan membentuk kecerdasan emosi dan kecerdasan spiritual anak. Setiap orang tua perlu emmahami bahwa kebahagiaan dan kesejahteraan tidak selalu berhubungan keberhasilan seseorang mendapatkan materi, akan tetapi diperoleh melalui penghayatan dan pengamalan ajaran agama dengan baik dan benar (Tarmujianto: 2020). Kedelapan, melakukan evaluasi secara berkala. Evaluasi yang dilakukan antar anggota keluarga tentunya dilakukan dengan santai tapi serius. Misal saat mengobrol bersama anak, ayah dapat menanyakan apakah ada yang tidak disukai dari ayah. Selain dengan anak, ayah dan ibu hendaknya saling mengevaluasi cara mendidik anak dan mengevaluasi juga dengan anggota keluarga yang lain. Nafisah (2020) menyatakan bahwa perlu adanya evaluasi dalam mendidik karakter anak. Hal ini supaya tujuan pengasuhan dapat tercapai dengan maksimal.

Jadi sesuai dengan keaadan di kecamatan Karangasem peran keluarga sangat penting dalam mempertahankan dan menguatkan ketahanan keluarga pada masa pandemi melalui pendidikan karakter yaitu prinsip pengasuhan anak kepada seluruh anggota keluarga dewasa yang ada dalam satu rumah, misal kakek, nenek, paman, bibi, dan sebagainya. Hal ini bertujuan supaya antar anggota keluarga memiliki kesepakatan cara mengasuh anak. Orang tua perlu menyatukan visi misi dalam mengasuh anak. Menyamakan pandangan tentang pengasuhan, karena kebanyakan orang tua mempelajari pengasuhan dari orang tua mereka masing-masing. Ayah dan ibu mungkin membawa pandangan yang berbeda mengenai pengasuhan anak. Oleh karena itu, perlu ada kesepakatan-kesepakatan supaya tidak menimbulkan kebingungan pada anak. Kerjasama 
antar anggota keluarga, sikap saling menghormati, komunikasi yang seimbang, dan penyesuaian terhadap kebutuhan masing-masing, akan membantu anak dalam membentuk sikap positif.

\section{Bentuk Implementasi Pendidikan Karakter Berbasis Keagamaan Dalam Memperkuat Ketahanan Keluarga Pada Masa Pandemi Di Kecamatan Karangasem}

Bentuk pendidikan karakter berbasis keagamaan dalam memperkuat ketahanan keluarga di Kecamatan Karangasem yaitu tercermin dalam ajaran Tri Kaya Parisuda yaitu olah pikir (manacika), olah rasa/karsa (wacika) dan olah raga (Kayika). Olah pikir (manacika) dari hasil observasi melalui wawancara bahwa olah pikir (manacika) ini merupakan bentuk implementasi yang dilakukan di Kecamatan Karangasem dalam memperkuat ketahanan keluarga di masa pandemi yaitu selalu berpikir yang positif terkait dengan pandemi yang telah terjadi dan berfikir terbuka untuk menghadapi pandemi serta tetap berinovasi dalam mendapatkan penghasilan untuk memenuhi tanggungjawab sebagai kepala keluarga, di samping itu dalam keluarga tidak boleh berfikir negative terhadap permasalahan yang terjadi pada keluarganya. Seperti yang telah terjadi di masa pandemi ini merupakan hal yang harus dilewati dan tetep berusaha bukan menanamkan jiwa putus asa. Pikiran yang positif akan mengantarkan penyelesaian masalah yang efektif jika dibandingkan sikap putus asa maka tindak pidana bisa terjadi. Dan dengan pikiran yang jernih dan positif maka akan timbul ketenangan.

Terkait dengan olah rasa (wacika) ini merupakan bentuk implementasi pendidikan karakter yang dilakukan di Kecamatan Karangasem dalam memperkuat ketahanan keluarga di masa pandemi. olah rasa (wacika) ini diimplementasikan sebagai upaya untuk menjalin rasa kekeluargaan yang tingi. Dengan perkataan yang tetap dijaga pasti akan

menimbulkan kedamaian, ketentraman, banyak mempunyai kerabat. Karena dalam kakawin Nitisasrra V.3 disebutkan sebagai berikut:

Wasita minittanta manemu laksmi

Wasita minittanta pati kapangguh

Wasita minittanta manemu dukha

Wasita minittanta menemu mitra

Terjemahan: 
Oleh perbuatan/ ucapan engkau akan mendapatkan bahagia, oleh perkataan/ucapan engkau mendapatkan kematian/ kehancuran, oleh perkataan/ ucapan engkau mendapatkan kesusahan/ kesedihan, oleh perkataan/ ucapan engkau mendapatkan sahabat/kawan.

Jadi seperti apa yang disampaikan di atas bahwa perkataan menimbulkan banyak hal yaitu dari ucapan akan mendapatkan bahagia, mendapatkan kematian/ kehancuran, mendapatkan kesusahan/ kesedihan, dan mendapatkan sahabat/ kawan. Terkait tentang penyampaian ucapan tetap dijaga agar rasa kekeluargaan tetap dijaga, apalagi di masa pandemi dengan berbagai masalah yang muncul terutama bidang ekonomi pasti seseorang akan mudah tersinggung jika sedikit saja ada ucapan yang diutarakan salah. Jadi dengan selalu memperhatikan ucapan yang akan dikeluarkan selalu berpikir terlebih dahulu. Hal ini sangat membuktikan ketahanan keluarga yang dialami tetap terjaga.

Walaupun keadaan ekonomi merosot akibat pandemi dengan menjaga sikap ini melalui penjelasan-penjelasan yang disampaikan di keluarga saat ini masih diterima dan tidak akan membuat pesimis untuk berusaha menikmati hidup di masa pandemi. Di samping itu, dalam hal bertindak maupun berkata jarang menyinggung perasaan. Hal tersebut dikarenakan sebelum berkata harus berpikir dahulu. Hal ini diterapkan oleh anggota keluarga. Hal yang ditanamkan untuk mengatasi konflik keluarga apalagi di masa pandemi ini yang berdampak di segala bidang uatamanya ekonomi adalah tetap Beriman dan Bertakwa, Jujur, dalam mengutarakan sesuatu, bertanggung jawab terhadap apa yang menjadi kewajiban, pantang menyerah walapun kegiatan sehari-hari menjadi penjual mengalami penurunan hasil yang diakibatkan oleh pandemi. Kemudian komunikasi tetap dijaga agar tidak ada perubahan di mana kehidupan dulu sebelum pandemi mudah memenuhi kebutuhan keluarga dan sekarang sangat sulit untuk mendapatkan penghasilan. Kendati demikian komunikasi/ucapan yang diterapkan di keluarga tetap terjaga selama ini tidak menimbulkan konflik apapun, karena melalui komunikasi yang baik bisa menyadarkan bahwa apa yang terjadi saat ini adalah memang harus terjadi dan wajib untuk dirasakan. Dengan prinsip tersebut ketahanan keluarga di masa pandemi tetap terjaga.

Olah raga (kayika) pada dasarnya sesuai dengan siklus "rwabhineda" perbuatan manusia dapat ditinjau dari dua sisi/dimensi yang berbeda, yaitu antara perbuatan yang baik (subha karma) dan perbuatan yang tidak baik/buruk (asubha karma). Perputaran/siklus subha dan asubha karma ini selalu saling bertautan dan silih berganti 
satu sama lainnya dan tidak dapat dipisahkan. Dalam perbuatan sehari-hari harus berpedoman pada ajaran agama, di mana dengan tuntunan ajaran agama dalam melakukan perbuatan tetap memperhatikan kebaikan. Pada masa pandemi ini perbuatan yang mengamalkan ajaran agama sangat perlu diimplementasikan. Jika di masa sulit seperti saat ini pandemi melanda pasti ada permasalahan-permasalah yang muncul baik dari keluarga maupun di masyarakat. Hal tersebut tidak terlepas dari adanya tanggung jawab untuk menghidupi keluarga. Dengan perbuatan yang baik diterapkan dari tempat yang terkecil yaitu di keluarg, apapun permasalahan hidup yang dialami pasti tetap bersabar dan tidak mudah emosi, pesimis, goyah, lalai dengan tanggung jawab.

Sebagai manusia dengan kekuatan idep/manah ini harus dengan cermat dapat memilah dan memilih perbuatan baik sehingga tidak terjerembak dalam perbuatan buruk lebih-lebih di masa pandemi seperti saat ini berbagai masalah melanda. sikap dan prilaku manusia selama hidup manusia berada pada dua jalur yang berbeda itu, sehingga patut dengan kesadaran budhi nuraninya (manusia) harus dapat menggunakan kemampuan berpikirnya kearah yang lebih baik dan benar. Apabila manusia sebagai makhluk berpikir (punya manah) mau dan mampu mengarahkan pikirannya ke arah yang baik akan mengakibatkan ucapan dan perilakunya menjadi baik (subha karma). Sebaliknya apabila tidak mampu mengarahkan pikiran (mengendalikannya) kearah yang baik, hal inilah mengakibatkan manusia berucap dan berbuat yang buruk (asubha karma). Dalam Sarasamuscaya ditegaskan bahwa hakekat penjelmaan sebagai manusia adalah untuk meningkatkan/menyempurnakan diri dari perbuatan buruk (asuba karma) menjadi perbuatan baik (subha karma).

Manusah sarwabhutesu, vartate vai subhasubhe asubhesu samavistam, subhesveva vakarayet

(Sarasamuscaya 2)

Terjemahan:

Di antara semua makhluk hidup hanya yang dilahirkan sebagai manusia sajalah yang dapat berbuat baik ataupun buruk. Leburlah ke dalam perbuatan baik segala perbuatan buruk itu. Demikianlah gunanya (pahalanya) menjadi manusia.

Apa yang diuraikan dan dijelaskan pada sloka tersebut di atas adalah tugas utama atau hakekat penjelmaan sebagai manusia, untuk melebur perbuatan buruk (asubha 
karma) menjadi perbuatan baik (subha karma). Hanya dengan berbuat baiklah manusia menunjukkan eksistensinya sebagai makhluk yang utama, sebagaimana disuratkan dalam Sarasamusca 4 sebagai berikut:

Apan ikingdadi wivang uttama juga ya, nimittaning mangkana wenang ya tumulung awaknya sakeng sangsara, makasadhanang subhakarma, hinganing kottamaning dadi wwang ika

Terjemahan :

Menjelma menjadi manusia itu adalah sungguh-sungguh utama, sebabnya demikian karena ia dapat menolong dirinya dari keadaan sengsara (lahir dan mati berulang-ulang) dengan jalan berbuat baik, demikianlah keutamaan keuntungan dapat menjelma menjadi manusia.

Jadi apa yang disampaikan melalui sloka di atas bahwa perbuatan yang baik harus dilakukan oleh manusia mengingat keutamaan menjelma menjadi manusia memiliki pikiran untuk memilah mana yang baik dan buruk. Di samping itu perbuatan juga akan mengantarkan manusia dalam kualitas kelahiran yang akan dating berdasarkan karma yang dilakukan oleh manusia.

Implementasi pendidikan karakter terutama dalam bertindak/berbuat. Dalam kehidupan sehari-hari manusia hendaknya dapat menjauhkan diri dari segala macam perbuatan yang dilarang oleh agama maupun norma-norma yang berlaku di masyarakat. Dengan perbuatan yang baik akan mngantarkan yang namanya kedamaian walapun permasalahan-permasalahan sering muncul. Contoh masalah saat pandemi banyak yang merasakan dampaknya. Jika tidak diimbangi ajaran agama yang kuat terutama dalam berbuat pasti akan sering menimbulkan konflik. Maka dari itu dalam keluarga selalu mengimplementasikan ajaran agama.

Jadi jelas bahwa apa yang dilakukan di masa pandemi ini tetap melakukan perbuatan-perbuatan yang sesuai dengan ajaran agama, dan menghindari perbuatan yang menentang agama. Hal tersebut sesuai ajaran agama yang tersurat alam Sarasamuscaya sloka 76 sebagai berikut:

Nihan yang tan ulahakena, syamatimati mangahalahal, si paradara, nahan tang telu tan ulahakena ring asing ring parihasa, ring ring apatkala ri pangipyan tuwi singgajana jugeka.

Terjemahannya: 
Inilah yang tidak patut dilakukan: membunuh,mencuri, berbuat zinah; ketiganya itu janganlah hendaknya dilakukan terhadap siapapun, baik secara berolok-olok, bersenda gurau, baik dalam keadaan dirundung malang, keadaan darurat dalam khayalan sekalipun, hendaknya dihindari saja ketiganya itu.

Dari beberapa pernyataan di atas bahwa dengan menerapkan pendidikan karakter, maka salah satu upaya yang dilakukan adalah menanamkan ajaran kayika dalam Tri Kaya Parisuda. Hal tersebut sebagai bentuk implementasi pendidikan karakter berbasis keagamaan untuk memperkuat ketahanan keluarga di masa pandemi yang dialami.

Jadi sesuai dengan penjelasan di atas dapat disampaikan bahwa bentuk Implementasi Pendidikan Karakter Berbasis Keagamaan dalam Memperkuat Ketahanan Keluarga Pada Masa Pandemi di Kecamatan Karangasem yaitu tercermin dalam ajaran Tri Kaya Parisuda yaitu olah pikir (manacika), olah rasa/karsa (wacika) dan olah raga (Kayika).

\section{Implikasi Pendidikan Karakter Berbasis Keagamaan Terhadap Ketahanan Keluarga Pada Masa Pandemi Di Kecamatan Karangasem}

Implikasi dari implementasi pendidikan karakter berbasis keagamaan dalam memperkuat ketahanan keluarga pada masa pandemi di Kecamatan Karangasem diperoleh dari hasil wawancara informan adalah :

Pertama, memperkuat ketahanan psikologis. Dampak dari pandemi covid-19 bisa menjadikan kehidupan terpuruk. Tekanan hidup yang tinggi bisa menimbulkan stress atau tekanan jiwa. Kebutuhan yang terus menuntut, lapangan kerja yang semakin sempit, kemampuan Teknologi yang sangat diperlukan, kebutuhan kuota yang menggila dan berbagai tekanan hidup menjadikan suasana hati semakin tertekan. Dibutuhkan kemampuan untuk mengelola emosi diri guna meningkatkan kematangan kepribadian. Mengembangakan pola pikir positif sangat diperlukan. Sehingga orangtua mampu menyikapi segala situasi dan kondisi dengan jiwa yang tenang dan pikiran yang lapang. Ketenangan hati menjadi awal yang baik untuk berpikir solusi lebih lanjut. Bila pikiran kalut, hati tertekan maka persoalan yang kecilpun bisa bertambah ruwet dan dapat menjadi pangkal persoalan keluarga yang lebih besar. Diperlukan kesadaran dan latihan untuk mampu mengendalikan diri dan menerima segala kondisi dengan ikhlas. Ikhlas bukan berarti menyerah, namun tetap berusaha dan terus berikhtiar untuk mencari solusi dan jalan keluar. Usaha diiringi doa, disertai jiwa iklas berserah diri kepada Tuhan menjadi sikap hidup yang sangat penting. Memelihara, mengembangkan, dan 
menguatkan konsep diri perlu terus dibangun. Mensyukuri setiap nikmat yang Tuhan berikan menjadi kata kunci dalam segala keadaan, agar hati menjadi ikhlas dan tenang.

Kedua, meningkatkan ketahanan ekonomi keluarga di masa pandemi. Situasi pandemi saat ini berdampak pada pertumbuhan ekonomi. Pertumbuhan ekonomi terus menurun, bahkan negatif. Jika hal ini terus berkalanjutan maka akan terjadi resesi. Tekanan ekonomi menjadi semakin berat. Kondisi yang dirasakan saat ini mendorong masyarakat untuk terus menggali, mengelola dan memanfaatkan sekecil apapun sumber daya yang dimiliki. Kebutuhan dasar yakni kebutuhan makan dan minum atau kebutuhan pangan menjadi tugas pertama untuk dipenuhi. Sumber penghasilan diupayakan harus ada. Tidak mesti menjadi pegawai negeri maupun swasta. Berwirausaha di segala bidang memberikan peluang yang tak terbatas. Berjualan kebutuhan hidup sehari-hari dengan layanan antar barang akan menjadi pilihan yang dicari. Selain itu perilaku hemat juga digerakkan. Pengelolaan keuangan makin hati-hati. Kebutuhan pokok harus didahulukan. Kepentingan pendidikan dan kesehatan juga diprioritaskan. Kebutuhan sekunder bisa ditunda kemudian, apalagi kebutuhan tersier. Beberapa hal sederhana juga bisa dilakukan, seperti menanam tanaman hortikultura di sekitar rumah. Menanam buah-buahan, sayuran dan ubiubian yang tidak memerlukan waktu lama untuk memanen. Setiap keluarga memanfaatkan sekecil apapun lahan yang ada, untuk dimanfaatkan sebagai sumber gizi keluarga. Bila lahan terbatas, maka menggunakan pola hidroponik juga dapat dilakukan untuk terselenggaranya gerakan keluarga menanam tanaman hortikultura, minimal sejumlah anggota dalam keluarga.

Ketiga, meningkatkan ketahanan sosial. Interaksi sosial perlu dijaga, walau dalam situasi pandemi. Interaksi dapat dilakukan secara luring (luar jaringan) maupun daring (dalam jaringan). Yang dilakukan saat pandemi harus memperhatikan protokol kesehatan sesuai kebijakan pemerintah. Komunikasi secara virtual bisa menjadi alternatif untuk dilakukan. Yang pasti komunikasi antar keluarga, saudara, teman terlaksana dengan baik dan tidak terputus. Kebersamaan sosial bisa dikuatkan. Jiwa gotong royong bisa dilaksanakan. Rasa kebersamaam terus dikembangkan. Bila seseorang memiliki kepedulian kepada masyarakat di sekitarnya, maka saat ia mengahapi kesulitan orang lainpun akan ringan memberikan bantuan dan dukungan. Kesediaan untuk membantu saudara dan tetangga tidak perlu menunggu kaya. Karena kaya itu sesungguhnya tidak pernah ada jika manusia tidak merasa cukup, dan terus berburu kekayaan. kebutuhan dan 
keinginan yang bersifat sekunder bisa ditunda, dialihkan untuk berbagi pada sesama. Dengan hal itu bisa menjadikan kehidupan lebih bermakna.

Keempat, meningkatkan ketahanan spiritual. Ajaran dan nilai agama adalah fondasi kehidupan manusia, yang harus dilakukan sebagai manusia. Dalam ketahanan spiritual telah dilakukan dengan sungguh-sungguh untuk menjalankan ajaran agama, dan menjadikan agama sebagai rujukan dan muara dalam menghadapi berbagai persoalan pada situasi pandemi. Apalagi siatuasi pandemi saat ini menyarankan anggota keluarga banyak berada di rumah.

Implikasi dari implementasi pendidikan karakter berbasis keagamaan dalam memperkuat ketahanan keluarga pada masa pandemi di Kecamatan Karangasem yang telah dilakukan melalui bentuk-bentuk implementasi pendidikan karakter berbasis keagamaan seperti yang tertuang dalam ajaran Hindu Tri Kaya Parisudha yaitu olah pikir (manacika), olah rasa/karsa (wacika) dan olah raga (Kayika) dapat berimplikasi mampu memperkuat ketahanan psikologis dengan kesadaran dan latihan untuk mampu mengendalikan diri dan menerima segala kondisi dengan ikhlas dan tetap berusaha dan terus berikhtiar untuk mencari solusi dan jalan keluar. Usaha diiringi doa, disertai jiwa iklas berserah diri kepada Tuhan, Meningkatkan ketahanan ekonomi keluarga di masa pandemi dengan memanfaatkan kesempatan yang ada demi memenuhi kebutuhan seharihari, Meningkatkan ketahanan sosial dengan tetap berjiwa gotong royong dan rasa kebersamaam terus dikembangkan, Meningkatkan ketahanan spiritual dengan tetap menjalankan ajaran agama, dan menjadikan agama sebagai rujukan dan muara dalam menghadapi berbagai persoalan pada situasi pandemi yang dialami oleh masyarakat terutama masyarakat di Kecamatan Karangasem.

\section{Kesimpulan}

Dari uraian di atas dapat ditarik suatu simpulan dalam penelitian ini untuk mendeskripsikan rumusan masalah sebagai berikut:

1. Pendidikan karakter berbasis keagamaan dalam memperkuat ketahanan keluarga pada masa pandemi perlu diimplementasikan di Kecamatan Karangasem. Mengingat banyak permasalahan yang dihadapi oleh masyarakat di Kecamatan Karangasem terutama permasalahan pada aspek pariwisata dan perdagangan, Maka dari itu peran keluarga dalam mengimplementasikan pendidikan karakter berbasis keagamaan sangat penting dan perlu di masa pandemi, tentulah akan mengalami sedikit 
perbedaan pada masa pandemi dan sebelum pandemi. Mengingat waktu yang dihabiskan bersama anak lebih banyak juga. Adapun beberapa hal yang harus diperhatikan keluarga dalam menanamkan pendidikan karakter pada anak di masa pandemi untuk ketahanan keluarga.

2. Bentuk implementasi pendidikan karakter berbasis keagamaan dalam memperkuat ketahanan keluarga pada masa pandemi di Kecamatan Karangasem yaitu tercermin dalam ajaran Tri Kaya Parisuda yaitu olah pikir (manacika), olah rasa/karsa (wacika) dan olah raga (Kayika).

3. Implikasi pendidikan karakter berbasis keagamaan terhadap ketahanan keluarga pada masa pandemi di Kecamatan Karangasem yaitu mampu memperkuat ketahanan psikologis dengan kesadaran dan latihan untuk mampu mengendalikan diri dan menerima segala kondisi dengan ikhlas dan tetap berusaha dan terus berikhtiar untuk mencari solusi dan jalan keluar. Usaha diiringi doa, disertai jiwa iklas berserah diri kepada Tuhan, Meningkatkan ketahanan ekonomi keluarga di masa pandemi dengan memanfaatkan kesempatan yang ada demi memenuhi kebutuhan sehari-hari, Meningkatkan ketahanan sosial dengan tetap berjiwa gotong royong dan rasa kebersamaam terus dikembangkan, Meningkatkan ketahanan spiritual dengan tetap menjalankan ajaran agama, dan menjadikan agama sebagai rujukan dan muara dalam menghadapi berbagai persoalan pada situasi pandemi.

\section{DAFTAR PUSTAKA}

Baal J Van. (1988). Sejarah dan Pertumbuhan Teori Antropologi Budaya. Jakarta : PT Gramedia.

Berry, John, dkk. (I999). Psikologi Lintas Budaya Riset aplikasi. Jakarta : Gramedia

Esten, Mursal. (1999). Desentralisasi Kebudayaan. Bandung : Percetakan Angkasa Anggota I KAPI.

Hartomo dan Aziz, Arnicum. (2004). Ilmu Sosial Dasar. Jakarta : Pt Bumi Aksara

Hasan, Zaini dan Salldin.(1996). Pengantar Ilmu Sosial. Jakarta :Departemen pendidikan dan Kebudayaan Direktorat jendral pendidikan Tinggi.

Ihromi, T.O. (1999). Bunga Rampai Sosiologi Keluarga. Jakarta: Yayasan Obor Jalaludin, H. (2002). Psikologi Agama. Jakarta : PT Raja Grafindo Persada. Joyomartono, Muliono. (I991). Perubahan Kebudayaan dan Masyarakat dalam Pembangunan. Semrang: IKIP Semrang. 
Koentjaranigrat. (1985). Pengantar Ilmu Antropologi. Jakarta : Fa. Aksara Baru

Moleong, Lexy. (1990). Metodologi Penelitian Kualitatif. Bandung: PT Remaja Rosdakarya.

Muhammad, Abdulkadir. (2005): Ilmu Budaya Dasar. Bandung: PT Citra aditya Bali.

Oktaria, R., \& Putra, P. (2002). Pendidikan Anak dalam Keluarga sebagai Strategi Pendidikan Anak Usia Dini saat Pandemi Covid-19. Jurnal Ilmiah PESONA PAUD, 7 (1), 41-51.

O”dea, Thomas. (1987). Sosiologi Agama Suatu Pengantar. Jakarta :Rajawali Pers.

Pelly, Usman. (1992). Teori-teori Sosial Budaya. Jakarta : Departemen Pendidikan dan Kebudayaan.

Prondizi, Risieri, (2001). Pengantar Filsafat Nilai. Yogyakarta : Pustaka Pelajar.

Santrock, J.W. (2011). Perkembangan Anak. Jakarta: Erlangga.

Soekanto, Soerjono. (2005). Sosiologi Suatu Pengantar. Jakarta : PT. Raja Grafindo Persada.

Sutisna. (2005). Pengantar Sosiologi. Jakarta: Balai Pustaka.

Syani, Abdul.(1995). Sosiologi dan Perubahan Masyarakat. Jakarta: Dunia Pustaka Jaya.

Sztompka, Piotr. (1993). Sosioligi Perubahan Sosial. Jakarta : Prenada Media Group.

Tafsir, A. (2014). Ilmu Pendidikan dalam Perspektif Islam. Bandung: Remaja Rosdakarya.

Warna, I Wayan, dkk. (1996). Kamus Indonesia-bali. Dinas Pendidikan Dasar, Provinsi Daerah Tingkat I Bali.

Tim Penyusun. (2001). Kamus Sanskerta Indonesia. Denpasar : Dinas Propensi Bali http:www.//belajarpsikologi.com/pengertian-pendidikan-karakter 